\title{
A meta-analysis and meta-regression of the effect of forage particle size, level, source, and preservation method on feed intake, nutrient digestibility, and performance in dairy cows
}

\author{
S. M. Nasrollahi, ${ }^{*}$ M. Imani, ${ }^{*}$ and Q. Zebeli† \\ *Department of Animal Science, University College of Agriculture and Natural Resources, University of Tehran, Karaj, Iran, \\ P.O. Box 3158711167-4111, Iran \\ †Institute of Animal Nutrition and Functional Plant Compounds, Department for Farm Animals and Veterinary Public Health, Vetmeduni Vienna, \\ Veterinaerplatz 1, 1210 Vienna, Austria
}

\section{ABSTRACT}

A meta-analysis of the effect of forage particle size (FPS) on nutrient intake, digestibility, and milk production of dairy cattle was conducted using published data from the literature (1998-2014). Meta-regression was used to evaluate the effect of forage level, source, and preservation method on heterogeneity of the results for FPS. A total of 46 papers and 28 to 91 trials (each trial consisting of 2 treatment means) that reported changes in FPS in the diet of dairy cattle were identified. Estimated effect sizes of FPS were calculated on nutrient intake, nutrient digestibility, and milk production and composition. Intakes of dry matter and neutral detergent fiber increased with decreasing FPS $(0.527$ and $0.166 \mathrm{~kg} / \mathrm{d}$, respectively) but neutral detergent fiber digestibility decreased $(0.6 \%)$ with decreasing FPS. Heterogeneity (amount of variation among studies) was significant for all intake and digestibility parameters and the improvement in feed intake only occurred with decreasing FPS for diets containing a high level of forage (>50\%). Also, the improvement in dry matter intake due to lowering FPS occurred for diets containing silage but not hay. Digestibility of dry matter increased with decreasing FPS when the forage source of the diet was not corn. Milk production consistently increased $(0.541 \mathrm{~kg} / \mathrm{d}$; heterogeneity $=19 \%)$ and milk protein production increased $(0.02 \mathrm{~kg} / \mathrm{d})$ as FPS decreased, but FCM was not affected by FPS. Likewise, milk fat percentage decreased $(0.058 \%)$ with decreasing FPS. The heterogeneity of milk parameters (including fat-corrected milk, milk fat, and milk protein), other than milk production, was also significant. Decreasing FPS in high-forage diets $(>50 \%)$ increased milk protein production by $0.027 \%$. Decreasing FPS increased milk protein content in corn forage-based diets and milk fat and protein percentage in hay-based diets. In conclu-

Received April 8, 2015.

Accepted August 5, 2015

${ }^{1}$ Coresponding author: smnasrolahi@ut.ac.ir sion, FPS has the potential to affect feed intake and milk production of dairy cows, but its effects depend upon source, level, and the method of preservation of forages in the diet.

Key words: forage particle size, forage level, forage source, forage preservation method, meta-analysis

\section{INTRODUCTION}

High-forage diets can prevent high-yielding dairy cows from acquiring their energy requirement due to physical limitations (i.e., filling effects) of intake (Allen, 2000). Therefore, forages are often physically processed to maximize intake of cows and to improve preservation method characteristics, as in the case of silages. Furthermore, chopping of forages finely helps to prevent sorting of the TMR (DeVries et al., 2008), ensuring that cows consume a diet similar to the formulated diet.

However, long forage particles are required in dairy diets to promote saliva secretion during eating and ruminating and reticuloruminal motility, which elevate ruminal $\mathrm{pH}$ and promote rumen health (Mertens, 1997). Low ruminal $\mathrm{pH}$ can lower fiber digestion (Russell and Wilson 1996), milk fat production (Zebeli et al., 2012), and reproductive performance (Walsh et al., 2011) of dairy cows. Numerous studies have been conducted to evaluate the effects of forage particle size (FPS) in dairy cow diets, but tremendous variation and inconsistency in the responses exist (Tafaj et al., 2007). It appears that the effects of FPS vary depending upon proportion of forage in the diet (Yang and Beauchemin, 2009), forage source (Krause and Combs, 2003), forage preservation method (i.e., hay vs. silage; Calberry et al., 2003), and other factors (Nasrollahi and Khorvash, 2014). There is a need to examine the results of these studies in a more comprehensive manner to understand the general relationships between FPS and performance of dairy cows.

Meta-analysis is a useful tool that can be used to both summarize effects of treatment across studies and to investigate factors explaining potential heterogeneity 
of response (Duffield et al., 2008). This technique has been used previously to summarize research findings and treatment effects in several aspects of dairy cow production (Duffield et al., 2008; Rabiee et al., 2012; Rabiee and Lean, 2013). Zebeli et al. (2006) and Tafaj et al. (2007) both used meta-analysis to investigate the effects of FPS on intake, rumen digestion, and milk production in high-yielding dairy cows. They reported that most of the performance responses (i.e., intake, digestion, and milk production) to FPS were not significant. However, lack of effects could have been due to the limited database used ( 25 papers or 55-93 treatment means). In addition, these studies did not consider the effect of forage level and preservation method due to the limited database. Since that time, additional studies have been published which would allow closer examination of those factors.

Therefore, the objective of our study was to conduct a comprehensive meta-analysis of the effects of FPS on nutrient intake and digestibility and milk production and composition. A second objective was to consider the effect of forage level, source, and preservation method on the heterogeneity response of FPS. We hypothesized that marginal effects of FPS on dairy cow performance would be detected and forage level, source, and preservation method would affect the responses to FPS.

\section{MATERIALS AND METHODS}

A literature search and screening process (limiting results to papers published 1998-2014) were initially conducted using Journal of Dairy Science, Journal of Animal Science, Animal Feed Science and Technology, Livestock Science, and Animal websites to create a data set of FPS papers using the key words "particle size," "particle length," "particle size and cow," "particle length and cow," "particle size and cattle," or "particle length and cattle." Authors of research on particle size were contacted to obtain reports and unpublished or published information not identified by other search methods. All study reports and papers were initially screened for acceptability by determining if the research conducted studied effects of FPS in dairy cow nutrition. After discarding papers that were not in this field, an initial data set of 81 papers was achieved.

\section{Selection for Inclusion and Exclusion Criteria}

For inclusion in the final database, papers must have been conducted on the changes of FPS in dairy cow nutrition. Thus, all review papers $(\mathrm{n}=5)$, herd-level analysis $(\mathrm{n}=4)$, and nontarget species papers (cows in late lactation or dry cows; $\mathrm{n}=5$ ) were excluded. Four studies were discarded that contained solely outcome measures that were not an outcome objective for our meta-analysis. Studies $(n=8)$ that considered changes in the physical form of the diet, other than mean particle size, were also removed. Likewise, studies with no in vivo measurements $(\mathrm{n}=3)$ were removed, as were studies published before $1997(\mathrm{n}=7)$ because the cows used in those studies did not represent modern dairy cows. Finally, 46 studies provided useable data and appropriate measures of variance on variable outcomes.

A template for data extraction was drafted, which included number of cows per treatment group, mean, and standard error. If the standard error was not published, it was estimated from either the exact $P$-values or other measures of variance, otherwise the data were excluded. In the case where a $P$-value was reported as less than a number (i.e., $P<0.05$ ), the number was used as the $P$-value for the standard error calculation. Other factors that influenced the outcomes of interest were included in the data extraction process including level, source, and preservation method of forage, grain source, concentration of starch, $\mathrm{NDF}, \mathrm{NE}_{\mathrm{L}}$, and DIM of cows. If starch or $\mathrm{NE}_{\mathrm{L}}$ content of the diet were not reported, they were predicted according to the diet formulation software CPM-Dairy (Cornell-Penn-Miner Dairy Version 3.08.01; http://cahpwww.vet.upenn.edu/ doku.php), a program to evaluate and formulate dairy cattle rations. Data from each study were extracted and entered into a relational database. For each paper, the diet with long FPS was considered as the control and the diet with short FPS was considered as the treatment. If more than 2 treatments were reported, the coarse and fine of the FPS of diet mean were compiled and reported, resulting in one control and one treatment value per analysis and trial. The level $(>50 \%$ and $\leq 50 \%$ ), source [corn and noncorn (alfalfa, grass, barley, oat, orchard grass)], and preservation method (silage and hay) of forage was noted for each treatment mean to allow subsequent exploration of their effects using meta-regression.

Outcomes used in our meta-analysis included nutrient intake and digestibility as well as milk yield and composition. Effect of FPS on these variables were also considered in relation to forage feeding including level, source, and preservation method.

\section{Statistical Analysis}

A meta-analysis was conducted on the extracted outcomes using $\mathrm{R}$ i386 3.0.1 (metafor package) and CMA2.0 (Comprehensive Meta-Analysis); the package is available via the Comprehensive R Archive Network (CRAN) at https://cran.r-project.org (Viechtbauer, 2010). The metafor package provides functions for fitting the various models. The various meta-analytic 
models can be fitted with rma() function; CMA was used for estimates of unreported standard errors in some studies. A random effect model was conducted for each treatment to estimate the effect size, $95 \%$ confidence intervals, and statistical significance of effect size.

$$
\theta_{\mathrm{i}}=\mu+\mathrm{u}_{\mathrm{i}},
$$

where $\mathrm{u}_{\mathrm{i}} \sim \mathrm{N}\left(0, \tau^{2}\right)$. Therefore, the true effects are assumed to be normally distributed with mean $\mu$ and variance $\tau^{2}$. The goal was then to estimate $\mu$, the average true effect, and $\tau^{2}$, the (total) amount of heterogeneity among the true effect. If $\tau^{2}=0$, then this implies homogeneity among the true effects (i.e., $\theta_{1}=\ldots=\theta_{\mathrm{k}}$ $=\theta$ ), so that $\mu=\theta$ denotes the true effect. For mean difference meta-analysis, it is acceptable to calculate a difference in mean values between the experimental and control groups for each study. Instead of calculating a difference in mean values between the experimental and control groups, it is also acceptable to calculate a ratio of mean values. The following method uses the natural logarithm scale to carry out such calculations, similar to statistical procedures for binary effect measures (risk ratio and odds ratio), due to its desirable statistical properties (Fleiss, 1993). For a study reporting a continuous outcome, let the mean, standard deviation, and number of observations be denoted by mean $_{\text {exp }}, \mathrm{sd}_{\text {exp }}$, and $\mathrm{n}_{\text {exp }}$, respectively, in the experimental group and mean $_{\text {contr }}$, $\mathrm{sd}_{\text {contr }}$, and $\mathrm{n}_{\text {contr }}$, respectively in the control group. The log-transformation of the ratio $\left[\mathrm{RoM}=\ln \left(\frac{\text { mean }_{\text {exp }}}{\text { mean }_{\text {contr }}}\right)\right]$ and the variance (Var) of its natural logarithm was estimated as follows:

$$
\operatorname{Var}\left[\ln \left(\frac{\text { mean }_{\text {exp }}}{\text { mean }_{\text {contr }}}\right)\right] \text {. }
$$

This approach is similar to that applied to other ratio methods, such as odds ratio and risk ratio, used for binary group comparison studies. As the ratio of means method is unitless, this method can be used irrespective of the units used in trial outcome measures. The program also allows the user to record data for subgroups within the study. For example, if there was a reason to believe that the treatment effect varied as a function of forage preservation method, some studies might report the treatment effect separately for hay and silage. In this case we would enter the data for each study on 2 rows - one for hay and one for silage - for nested (or subgroup) meta-regression. When study estimates of treatment differences were available for different sub- groups of treatments, the meta-regression technique was used to explore the variation in the magnitude of the treatment difference between these subgroups. When the subgroups were represented by a factor with q levels, the fixed effects model was extended as follows:

$$
\hat{\theta}_{\mathrm{ki}}=\beta_{1}+\eta_{\mathrm{ki}}+\varepsilon_{\mathrm{ki}}
$$

where $\hat{\theta}_{\mathrm{ki}}$ is the estimate of treatment difference from the kth subgroup in the ith study, for $\mathrm{k}=1, \ldots, \mathrm{q}$ and $\mathrm{i}$ $=1, \ldots, \mathrm{r}$. The term $\eta_{\mathrm{ki}}$ is equal to $\beta_{2} \times 2_{\mathrm{ki}}$. The error term, $\varepsilon_{\mathrm{ki}}$, was assumed to be normally distributed. Variation in experiment level effect size was assessed with a $\chi^{2}$ test for heterogeneity. An $\alpha$-level of 0.10 was used because of the relatively low power of the $\chi^{2}$ test to detect heterogeneity among the experiments. Heterogeneity of results among trials was quantified using the $\mathrm{I}^{2}$ statistic (Higgins et al., 2003). The $\mathrm{I}^{2}$ statistic describes the percentage of total variation across studies due to heterogeneity rather than chance. Where $\mathrm{Q}$ is the $\chi^{2}$ heterogeneity statistic and $\mathrm{k}$ is the number of trials, $\mathrm{I}^{2}$ was calculated as:

$$
\mathrm{I}^{2}=\frac{\mathrm{Q}-(\mathrm{k}-1)}{\mathrm{Q}} \times 100
$$

Uncertainty intervals for $\mathrm{I}^{2}$ (dependent on $\mathrm{Q}$ and $\mathrm{k}$ ) were calculated. Publication bias was investigated both graphically with funnel plots and statistically using tests from Begg and Manumdar (1994) and Egger et al. (1997). In the case of significant publication bias, the number of studies needed to reverse the reported findings (Fail-Safe n) was calculated based on Rosenthal's methods (Rosenthal, 1979).

\section{RESULTS}

A summary of the papers used for the various metaanalyses is provided in Table 1 . We used 45 papers containing 95 trials with FPS and performance outcomes. The diet condition of each paper regarding level, source, and preservation method of forage, source of grain, DIM of cows, and concentration of starch, NDF, $\mathrm{CP}$, and $\mathrm{NE}_{\mathrm{L}}$ of the diets were also reported in Table 1. Diets contained 35 to $80 \%$ forage (DM basis), consisting of corn, alfalfa, grass, barley, oat, and orchard grass, and were preserved in 2 forms, such as silage and hay.

\section{Meta-Analysis for Intake and Digestibility}

The meta-analysis findings for the effect of FPS on nutrient intake and digestibility are reported in Table 2. Dry matter intake increased with decreasing FPS; 
Table 1. Summary of papers used for meta-analysis of performance effects of forage particle size in lactating dairy cows

\begin{tabular}{|c|c|c|c|c|c|c|}
\hline Study & Trials, no. & Forage, $\%$ & Forage source & $\begin{array}{l}\text { Forage } \\
\text { preservation }\end{array}$ & DIM & Outcomes measured \\
\hline Le Liboux and Peyraud, 1998 & 1 & 68 & Alfalfa & Hay & 112 & Intake, digestibility, and milk \\
\hline Jenkins et al., 1998 & 1 & 50 & Alfalfa & Hay & 44 & Intake, digestibility, and milk \\
\hline Clark and Armentano, 1999 & 4 & 53 and 50 & Corn & Silage & 102 and 111 & Intake and milk \\
\hline Le Liboux and Peyraud, 1999 & 1 & 69 & Alfalfa & Hay & 136 & Intake, digestibility, and milk \\
\hline Bal et al., 2000 & 2 & 50 & Corn & Silage & 71 & Intake, digestibility, and milk \\
\hline Soita et al., 2000 & 2 & 55 and 45 & Barley & Silage & & Intake and milk \\
\hline Yang et al., 2001 & 1 & & Barley & Silage & 134 & Intake, digestibility, and milk \\
\hline Clark and Armentano, 2002 & 4 & 47 and 51 & Alfalfa & Silage & 86 & Intake \\
\hline Krause et al., 2002 & 2 & 39 & Alfalfa & Silage & 61 & Intake, digestibility, and milk \\
\hline Schwab et al., 2002 & 2 & 60 & Corn & Silage & 102 & Intake, digestibility, and milk \\
\hline Beauchemin et al., 2003 & 2 & 40 & Alfalfa & Hay & 127 & Intake, digestibility, and milk \\
\hline Johnson et al., 2003 & 3 & 40 & Corn & Silage & 217 and 128 & Intake, digestibility, and milk \\
\hline Kononoff and Heinrichs, 2003a & 1 & 57 & Corn & Silage & 17 & Intake, digestibility, and milk \\
\hline Kononoff and Heinrichs, 2003b & 3 & 50 & Alfalfa & Haylage & 19 & Intake, digestibility, and milk \\
\hline Kononoff et al., 2003 & 3 & 57 & Corn & Silage & 110 & Intake and milk \\
\hline Krause and Combs, 2003 & 3 & 40 & Alfalfa & Silage & 48 & Intake, digestibility, and milk \\
\hline Onetti et al. 2003 & 2 & 50 & Corn & Silage & 120 & Intake and milk \\
\hline Einarson et al., 2004 & 2 & 42 and 59 & Barley & Silage & 104 & Intake and milk \\
\hline Fernandez et al., 2004 & 2 & 75 & Corn & Silage & 62 & Intake, digestibility, and milk \\
\hline Onetti et al., 2004 & 1 & 50 & Alfalfa & Hay & 117 & Intake and milk \\
\hline Teimouri Yansari et al., 2004 & 2 & 40 & Alfalfa & Hay & 81 & Intake, digestibility, and milk \\
\hline Leonardi et al. 2005 & 4 & 50 & Oat & Silage & 60 & Intake and milk \\
\hline Soita et al., 2005 & 2 & 55 and 45 & Corn & Silage & 110 & Intake and milk \\
\hline Yang and Beauchemin, 2005 & 2 & 42 & Corn & Silage & 48 & Intake, digestibility, and milk \\
\hline Couderc et al., 2006 & 3 & 58 and 62 & Corn & Silage & & Intake and milk \\
\hline Yang and Beauchemin, 2006a & 2 & 47 & Barley & Silage & 189 & Intake \\
\hline Yang and Beauchemin, 2006b & 2 & 46 & Corn & Silage & 120 & Intake, digestibility, and milk \\
\hline Bhandari et al., 2007 & 4 & 43 & Alfalfa and corn & Silage & 78 & Intake and milk \\
\hline Yang and Beauchemin, 2007 & 2 & 35 and 60 & Alfalfa & Silage & 65 & Intake, digestibility, and milk \\
\hline Zebeli et al., 2007 & 2 & 80 and 40 & Hay & Hay & 195 & Intake and digestibility \\
\hline Bhandari et al., 2008 & 4 & 48 & Alfalfa and oat & Silage & 65 & Intake and milk \\
\hline Alamouti et al., 2009 & 1 & 38 & Alfalfa & Hay & 146 & Intake, digestibility, and milk \\
\hline Teimouri Yansari and & 2 & 40 & Alfalfa & Hay & 11 & Intake, digestibility, and milk \\
\hline \multicolumn{7}{|l|}{ Primohammadi, 2009} \\
\hline Yang and Beauchemin, 2009 & 2 & 35 and 60 & Alfalfa & Silage & 125 & Intake and milk \\
\hline Zebeli et al., 2009 & 2 & 50 & Corn & Silage & 91 & Intake, digestibility, and milk \\
\hline Maulfair et al.. 2010 & 3 & 58.8 & Grass & Hay & 90 & Intake and milk \\
\hline Storm and Kristensen, 2010 & 1 & 65 & Grass & Hav & 121 & Intake, digestibility, and milk \\
\hline Behgar et al., 2011 & 1 & 40 & Alfalfa & Hay & 47 & Intake, digestibility, and milk \\
\hline Maulfair et al.. 2011 & 3 & 58.8 & Grass & Hay & 90 & Digestibility \\
\hline Kammes and Allen, 2012 & 1 & 50 & Orchard- grass & Silage & 164 & Intake, digestibility, and milk \\
\hline Kammes et al., 2012 & 1 & 47 & Alfalfa & Silage & 177 & Intake, digestibility, and milk \\
\hline Nasrollahi et al., 2012 & 2 & 40 & Alfalfa & Hay & 175 & Intake and digestibility \\
\hline Kahyani et al., 2013 & 2 & 40 & Alfalfa & Hay & 88 & Intake, digestibility, and milk \\
\hline Maulfair and Heinrichs, 2013 & 2 & 58 & Corn & Silage & 115 & Intake and milk \\
\hline Puggaard et al., 2013 & 1 & 51 & Grass & Hav & 222 & Intake, digestibility, and milk \\
\hline
\end{tabular}


Table 2. The effect size estimates of forage particle size on nutrient intake and digestibility in lactating dairy cows derived from meta-analysis ${ }^{1}$

\begin{tabular}{|c|c|c|c|c|c|c|c|}
\hline Item & $\begin{array}{c}\text { SMD } \\
(95 \% \text { CI })\end{array}$ & Studies, no. & Effect size $(95 \% \mathrm{CI})$ & $\mathrm{SE}$ & $P$-value & $\mathrm{I}^{2}$ & $P$-value \\
\hline \multicolumn{8}{|c|}{ Intake $(\mathrm{kg} / \mathrm{d})$} \\
\hline DM & $0.527(0.300,0.754)$ & 88 & $0.024(0.014,0.033)$ & 0.005 & $<0.01$ & 71 & $<0.01$ \\
\hline NDF & $0.166(0.048,0.285)$ & 60 & $0.023(0.005,0.041)$ & 0.009 & 0.01 & 84 & $<0.01$ \\
\hline Starch & $0.147(-0.194,0.488)$ & 27 & $0.015(-0.174,0.047)$ & 0.017 & 0.37 & 80 & $<0.01$ \\
\hline \multicolumn{8}{|c|}{ Digestibility (\%) } \\
\hline NDF & $-1.610(-0.731,-0.490)$ & 49 & $-0.033(-0.057,0.008)$ & 0.013 & 0.01 & 85 & $<0.01$ \\
\hline Starch & $0.102(-0.260,0.465)$ & 29 & $0.001(-0.003,0.004)$ & 0.002 & 0.6083 & 59 & $<0.01$ \\
\hline
\end{tabular}

${ }^{1} \mathrm{SMD}=$ Studentized mean deference; $\mathrm{I}^{2}=$ degree of heterogeneity among studies included in the meta-analysis.

feeding finer particles increased DMI by $0.527 \mathrm{~kg} / \mathrm{d}$. Also, a similar increasing effect on NDF intake was reported. In contrast, the intake of $\mathrm{OM}$ and starch was not affected by decreasing FPS. Digestibility of DM and NFC was not affected by FPS. However, NDF digestibility significantly decreased (1.61\%) and OM digestibility tended to decrease with decreasing FPS.

The forest plot of the effect of forage particle size on DMI (Figure 1) and DM digestibility (Figure 2) reveals a considerable variation between studies. Also, as reported in Table 2 , the heterogeneity for all variable was more than $59 \%$ and statistically significant. Heterogeneity for NDF intake and NDF and OM digestibility were at the highest level (84-85\%), and for NFC digestibility were at the lowest level but still as high as $59 \%$. The high heterogeneity qualified the variables to be explored with meta-regression for some important variable in forage feeding condition. As result, data of intake and digestibility were subjected to a metaregression for the effect of FPS nested within forage level, source, and preservation method.

\section{Meta-Regression Analysis for Intake and Digestibility}

The meta-regression finding of current study revealed that decreasing FPS affects nutrient intake differently in different forage level in the diet (Table 3). At a high level of forage $(>50 \%$ in DM), DMI $(P<0.01)$ and starch intake $(P=0.04)$ increased as FPS decreased. In contrast, intake of DM $(P=0.02), \mathrm{OM}(P<0.01)$, and NDF $(P<0.01)$ decreased with decreasing FPS at lower levels of forage in the diet.

The intake of NDF was the only parameter that was affected differently between different forage sources (Table 3). The intake of NDF decreased with decreasing FPS for noncorn based-diets but was not affected in corn-based diets. Interestingly, forage preservation method had a considerable effect on nutrient intake due to decreasing FPS (Table 3). Decreasing FPS decreased DMI and NDF intake and tended to decrease OM in- take when hay was fed. However, decreasing FPS had no influence on nutrient intake in cows fed with silage as forage source. The starch intake was not affected with decreasing FPS neither in hay- nor in silage-based diets.

The meta-regression analysis revealed that changes in FPS similarly affect nutrient digestibility at both forage levels, and differently affect DM and starch digestibility for various forage sources and starch digestibilities in various preservation method forms of the forage (Table 4). Among all nutrient digestibility parameters, OM digestibility only tended to increase with decreasing FPS in high levels of forage. The digestibility of DM increased with decreasing FPS in noncorn forage-based diets, but not in corn forage-based diets. In contrast to noncorn forage-based diets, in corn-based diets starch digestibility decreased with decreasing FPS. Moreover, starch digestibility decreased in silage-based diets and increased in hay-based diets with decreasing FPS.

\section{Meta-Analysis for Milk Production and Composition}

The findings of current study revealed that milk production and composition were affected differently by decreasing FPS (Table 5). Milk production increased with decreasing FPS $(P<0.01)$. Indeed, cows fed finer particles produced $0.541 \mathrm{~kg}$ of milk/d more than cows fed coarser forage particles. Similarly, daily production of protein increased with decreasing FPS. In contrast to daily milk and protein production, fat percentage decreased with decreasing FPS. Conversely, feeding forage with coarser particle increased the percentage of fat by $0.06 \%$. Daily production of FCM and fat were not affected by decreasing FPS.

The forest plot of milk production data of the studies subjected to the meta-analysis revealed relatively lesser variation within studies (Figure 3), which was in agreement with the low heterogeneity of these variables. However, the forest plot of milk fat percentage (Figure 4) and its heterogeneity test indicates a high variation 
within study. Therefore, these variables were subjected to a further meta-regression for identifying the sources of this variation.

\section{Meta-Regression for Milk Production and Composition}

Forage level was as an important factor regarding the effect of FPS on milk fat percentage and protein yield (Table 6). Indeed, milk fat percentage increased with decreasing FPS only at low levels of forage inclu- sion, whereas the yield of milk protein increased as FPS decreased but only at high levels of forage feeding. The effect of FPS on other parameters of milk production and composition were not affected by level of forage feeding.

Forage source also influenced the effect of FPS on milk protein yield in which diets based on corn forage, in contrast to noncorn forage-based diets, increased daily protein yield (Table 6). However, forage source was insignificant to modulate the effects of FPS on other milk production and composition variables. In

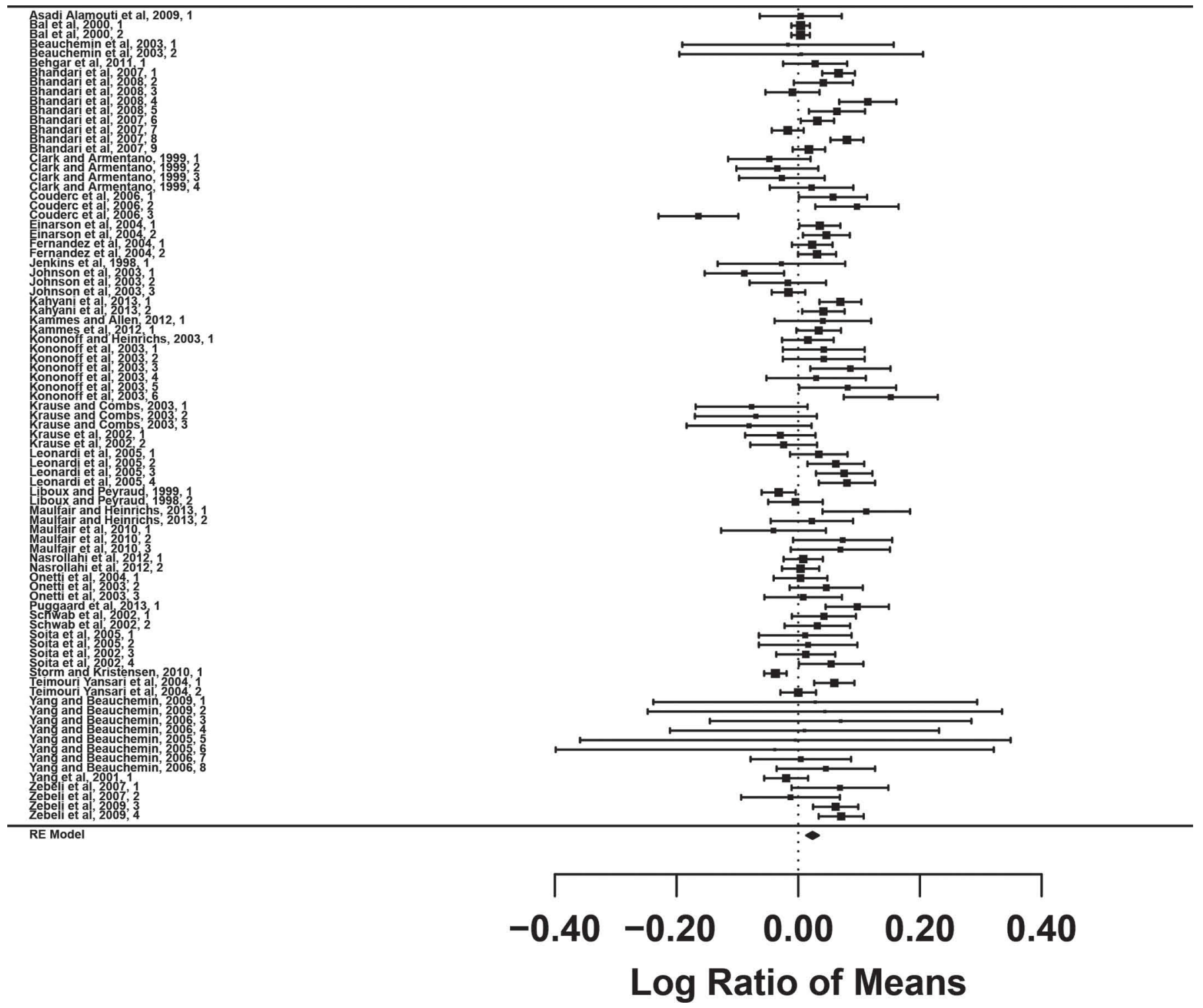

Figure 1. Forest plot of the effect of forage particle size on DMI in lactating dairy cows. The x-axis shows standardized mean difference (standardized using the z-statistic); thus, points to the left of the line represent a reduction in the trait, whereas points to the right of the line indicate an increase. Each square represents the mean effect size for that study, and the size of the square reflects the relative weighting of the study to the overall effect size estimate with larger squares representing greater weight. The upper and lower limit of the line connected to the square represents the upper and lower 95\% confidence interval for the effect size. The diamond at the bottom represents the $95 \%$ confidence interval for the overall estimate, and the dotted vertical line represents a mean difference of zero or no effect. 


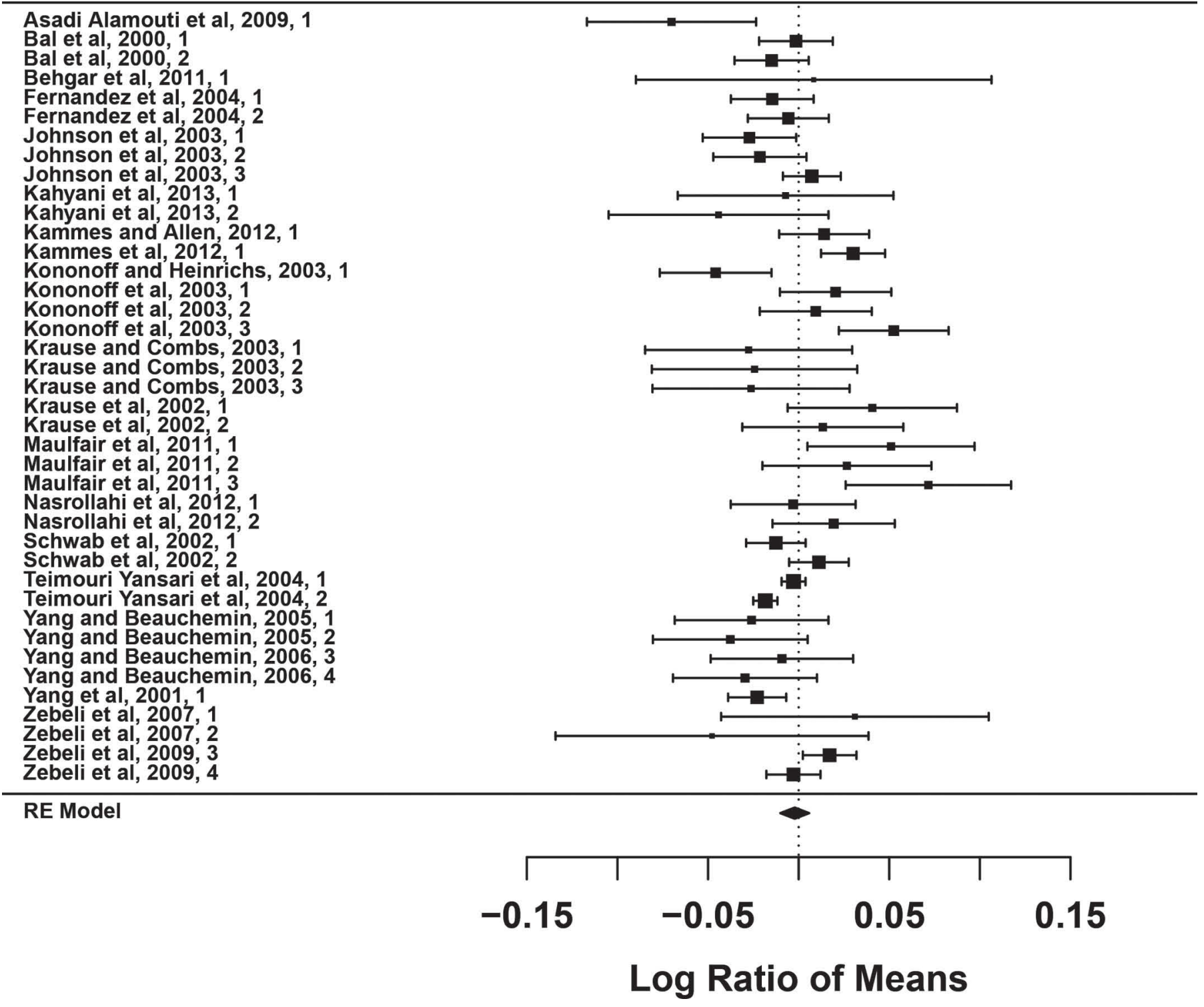

Figure 2. Forest plot of the effect of forage particle size on DM digestibility in lactating dairy cows. The x-axis shows standardized mean difference (standardized using the z-statistic); thus, points to the left of the line represent a reduction in the trait, whereas points to the right of the line indicate an increase. Each square represents the mean effect size for that study, and the size of the square reflects the relative weighting of the study to the overall effect size estimate with larger squares representing greater weight. The upper and lower limit of the line connected to the square represents the upper and lower $95 \%$ confidence interval for the effect size. The diamond at the bottom represents the $95 \%$ confidence interval for the overall estimate, and the dotted vertical line represents a mean difference of zero or no effect.

contrast to silage-based diets, in hay-based diets decreasing FPS increased milk fat and protein percentage (Table 6). Daily production of milk, FCM, protein, and fat responded similarly to FPS in 2 different methods of forage preservation.

\section{DISCUSSION}

Optimization of FPS is a key aspect in dairy cattle nutrition. Typically, long FPS is suggested in dairy cattle diets to provide sufficient physical effectiveness for forages to maintain normal rumen function (Tafaj et al., 2007). Conversely, long FPS is known to limit DMI and performance of the cows due to rumen fill effects of long FPS (Allen, 2000; Zebeli et al., 2006). Therefore, our meta-analysis and meta-regression was undertaken to evaluate the effect of FPS on feed intake and performance by also considering other factors, such as source and preservation method of forage as well as forage level in the diet. Indeed, we found improvements in DM and NDF intake with decreasing FPS, indicating a less-filling effect of fine particles. It is also possible 
Table 3. The effect of forage particle size nested in level, source, and preservation method of forage on nutrient intake (kg/d) in lactating dairy cows derived from meta-regression

\begin{tabular}{|c|c|c|c|c|c|c|c|c|c|c|}
\hline \multirow[b]{2}{*}{ Item } & \multirow[b]{2}{*}{ Level } & \multirow[b]{2}{*}{ Measurement } & \multicolumn{2}{|c|}{ DM } & \multicolumn{2}{|c|}{$\mathrm{OM}$} & \multicolumn{2}{|c|}{$\mathrm{NDF}$} & \multicolumn{2}{|c|}{ Starch } \\
\hline & & & Intercept & $\mathrm{DF}^{1}$ & Intercept & $\mathrm{DF}$ & Intercept & DF & Intercept & DF \\
\hline \multirow[t]{6}{*}{ Forage level } & High $(>50 \%)$ & $\beta^{2}$ & 0.001 & 0.035 & & & & & -0.066 & 0.092 \\
\hline & & SE & 0.007 & 0.006 & & & & & 0.068 & 0.046 \\
\hline & & $P$-value & 0.92 & $<0.01$ & & & & & 0.33 & 0.04 \\
\hline & Low $(\leq 50 \%)$ & $\beta$ & 0.029 & -0.014 & 0.034 & -0.024 & 0.031 & -0.022 & & \\
\hline & & $\mathrm{SE}$ & 0.009 & 0.006 & 0.012 & 0.007 & 0.012 & 0.009 & & \\
\hline & & $P$-value & $<0.01$ & 0.02 & $<0.01$ & $<0.01$ & 0.01 & 0.02 & & \\
\hline \multirow[t]{6}{*}{ Forage source } & Corn & $\beta$ & 0.043 & -0.006 & & & & & & \\
\hline & & SE & 0.014 & 0.009 & & & & & & \\
\hline & & $P$-value & $<0.01$ & 0.55 & & & & & & \\
\hline & Not corn & $\beta$ & 0.023 & -0.005 & & & 0.035 & -0.022 & -0.075 & 0.022 \\
\hline & & $\mathrm{SE}$ & 0.009 & 0.007 & & & 0.012 & 0.009 & 0.038 & 0.017 \\
\hline & & $P$-value & 0.02 & 0.43 & & & $<0.01$ & 0.01 & 0.05 & 0.19 \\
\hline \multirow[t]{6}{*}{ Forage preservation } & Silage & $\beta$ & 0.032 & 0.004 & & & & & & \\
\hline & & $\mathrm{SE}$ & 0.012 & 0.008 & & & & & & \\
\hline & & $P$-value & $<0.01$ & 0.60 & & & & & & \\
\hline & Hay & $\beta$ & 0.022 & -0.013 & 0.043 & -0.024 & 0.049 & -0.037 & & \\
\hline & & SE & 0.010 & 0.007 & 0.016 & 0.013 & 0.010 & 0.008 & & \\
\hline & & $P$-value & 0.02 & 0.05 & $<0.01$ & 0.07 & $<0.01$ & $<0.01$ & & \\
\hline
\end{tabular}

${ }^{1}$ Difference between coarse and fine FPS of diet as independent variable.

${ }^{2}$ Regression coefficient of the dependent variable [the effect size of FPS in each item (e.g., DMI, OM, and so on)] from the independent variable (intercept or DF)].

Table 4. The effect of forage particle size nested in different level, source, and preservation method of forage on nutrient digestibility (\%) in lactating dairy cows derived from meta-regression

\begin{tabular}{|c|c|c|c|c|c|c|c|c|c|c|}
\hline \multirow[b]{2}{*}{ Item } & \multirow[b]{2}{*}{ Level } & \multirow[b]{2}{*}{ Measurement } & \multicolumn{2}{|c|}{$\mathrm{DM}$} & \multicolumn{2}{|c|}{$\mathrm{OM}$} & \multicolumn{2}{|c|}{ NDF } & \multicolumn{2}{|c|}{ Starch } \\
\hline & & & Intercept & $\mathrm{DF}^{1}$ & Intercept & $\mathrm{DF}$ & Intercept & DF & Intercept & DF \\
\hline \multirow[t]{6}{*}{ Forage level } & High $(>50 \%)$ & $\beta^{2}$ & & & -0.005 & 0.009 & & & & \\
\hline & & $\mathrm{SE}$ & & & 0.008 & 0.006 & & & & \\
\hline & & $P$-value & & & 0.52 & 0.10 & & & & \\
\hline & Low $(\leq 50 \%)$ & $\beta$ & -0.010 & 0.000 & & & -0.034 & -0.000 & & \\
\hline & & $\mathrm{SE}$ & 0.005 & 0.003 & & & 0.011 & 0.006 & & \\
\hline & & $P$-value & 0.03 & 0.96 & & & $<0.01$ & 0.96 & & \\
\hline \multirow[t]{6}{*}{ Forage source } & Corn & $\beta$ & & & & & & & 0.004 & -0.003 \\
\hline & & $\mathrm{SE}$ & & & & & & & 0.002 & 0.001 \\
\hline & & $P$-value & & & & & & & 0.09 & $<0.01$ \\
\hline & Not corn & $\beta$ & -0.005 & 0.009 & & & -0.024 & 0.013 & & \\
\hline & & $\mathrm{SE}$ & 0.005 & 0.003 & & & 0.013 & 0.008 & & \\
\hline & & $P$-value & 0.27 & $<0.01$ & & & 0.08 & 0.13 & & \\
\hline \multirow[t]{6}{*}{ Forage preservation } & Silage & $\beta$ & & & & & & & 0.004 & -0.003 \\
\hline & & $\mathrm{SE}$ & & & & & & & 0.002 & 0.001 \\
\hline & & $P$-value & & & & & & & 0.08 & $<0.01$ \\
\hline & Hay & $\beta$ & -0.009 & 0.005 & & & -0.026 & 0.006 & -0.036 & 0.017 \\
\hline & & $\mathrm{SE}$ & 0.005 & 0.004 & & & 0.013 & 0.009 & 0.013 & 0.006 \\
\hline & & $P$-value & 0.07 & 0.18 & & & 0.05 & 0.50 & $<0.01$ & $<0.01$ \\
\hline
\end{tabular}

${ }^{2}$ Regression coefficient of the dependent variable [the effect size of FPS in each item (e.g., DMI, OM, and so on)] from the independent variable (intercept or DF). 
Table 5. The effect size estimates of forage particle size on milk production and composition in lactating dairy cows derived from meta-analysis ${ }^{1}$

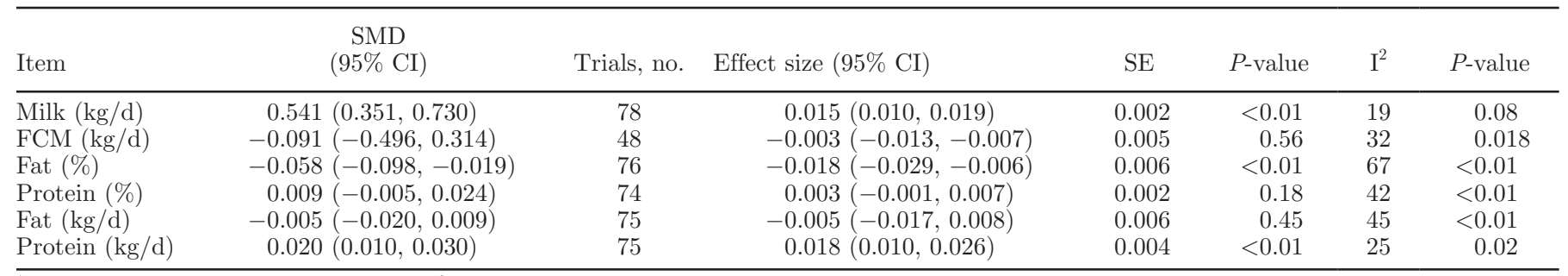

${ }^{1} \mathrm{SMD}=$ Studentized mean deference; $\mathrm{I}^{2}=$ degree of heterogeneity among studies included in the meta-analysis.

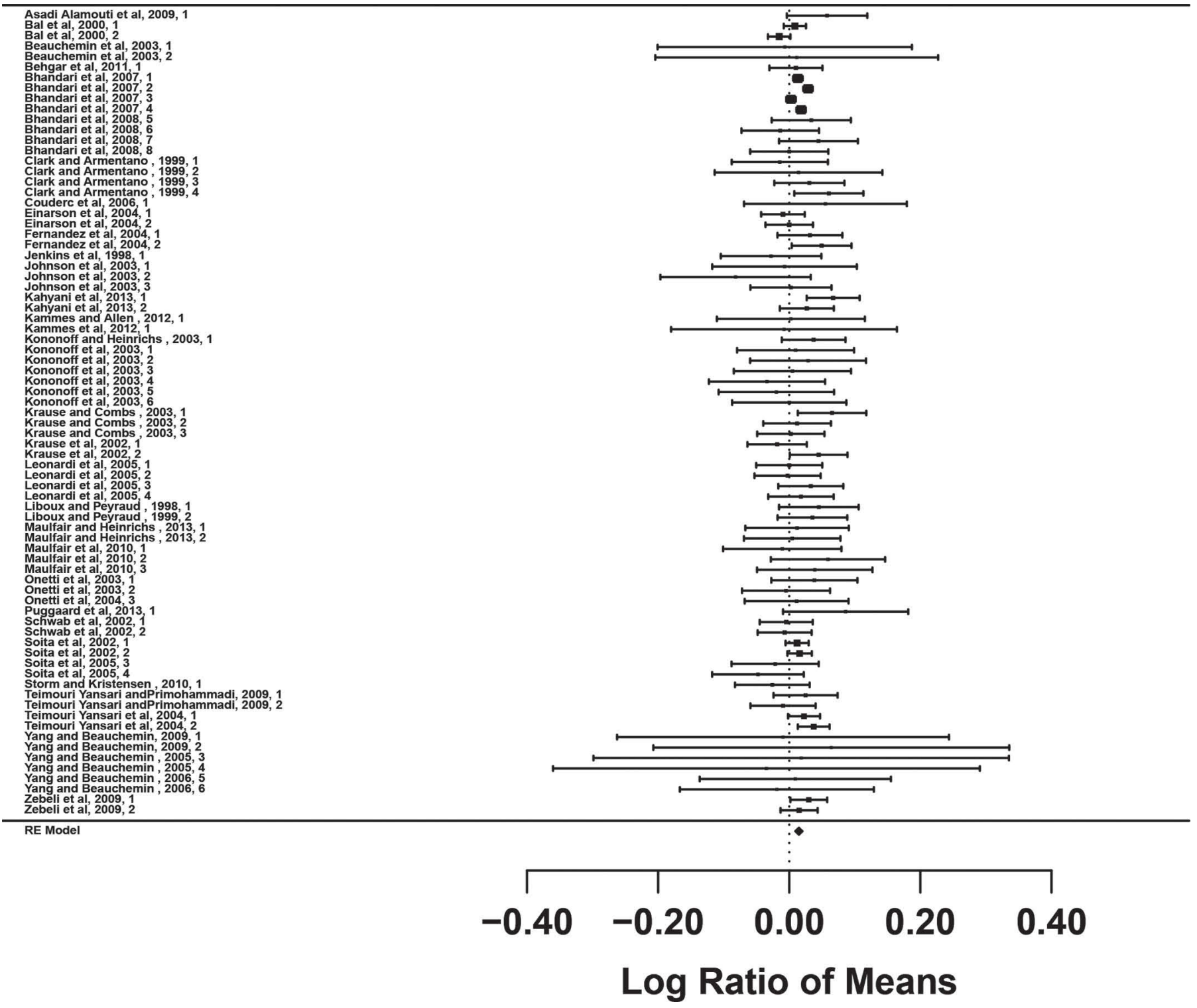

Figure 3. Forest plot of the effect of forage particle size on milk yield in lactating dairy cows. The x-axis shows standardized mean difference (standardized using the z-statistic); thus, points to the left of the line represent a reduction in the trait, whereas points to the right of the line indicate an increase. Each square represents the mean effect size for that study, and the size of the square reflects the relative weighting of the study to the overall effect size estimate with larger squares representing greater weight. The upper and lower limit of the line connected to the square represents the upper and lower 95\% confidence interval for the effect size. The diamond at the bottom represents the $95 \%$ confidence interval for the overall estimate, and the dotted vertical line represents a mean difference of zero or no effect. 
that feeding fine FPS lowers eating time and improves palatability of the feed, factors that affect feed intake in ruminants (Van Soest, 1994; Zom et al., 2012). The improvement in DMI by more than $0.5 \mathrm{~kg} / \mathrm{d}$ without decreasing DM digestibility indicates improvement in the uptake of many dietary nutrients with decreasing FPS. However, decreasing NDF digestibility could be considered as trade-off for the improvement of DMI due to decreasing FPS. This decrease in NDF digestibility might be due to decreasing rumen $\mathrm{pH}$ or increasing pas- sage rate, 2 events that are important for digestion of slowly digestible fiber particles (Mertens, 1993). From a practical viewpoint, the increase of DMI by decreasing FPS might be beneficial to enhance nutrient and energy intake of high-yielding dairy cows in early lactation due to their energy deficit, as the increase in DMI by $0.5 \mathrm{~kg}$ DM results in almost 3 to $4 \mathrm{MJ}$ of additional $\mathrm{NE}_{\mathrm{L}}$ intake per day.

The heterogeneity between studies was expected and indicated that other variables might influence the effect

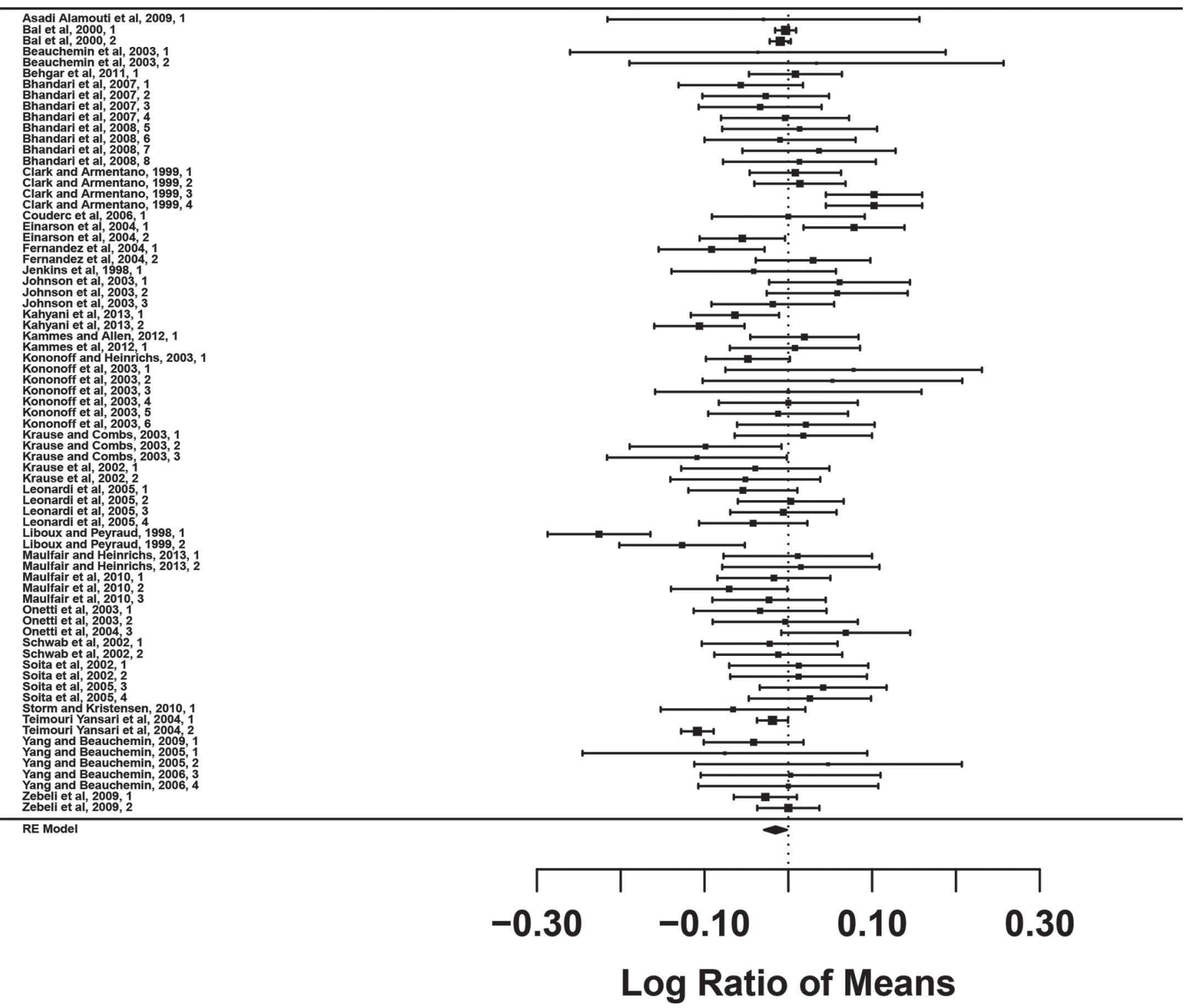

Figure 4. Forest plot of the effect of forage particle size on milk fat percentage in lactating dairy cows. The x-axis shows standardized mean difference (standardized using the z-statistic); thus, points to the left of the line represent a reduction in the trait, whereas points to the right of the line indicate an increase. Each square represents the mean effect size for that study, and the size of the square reflects the relative weighting of the study to the overall effect size estimate with larger squares representing greater weight. The upper and lower limit of the line connected to the square represents the upper and lower $95 \%$ confidence interval for the effect size. The diamond at the bottom represents the $95 \%$ confidence interval for the overall estimate, and the dotted vertical line represents a mean difference of zero or no effect. 


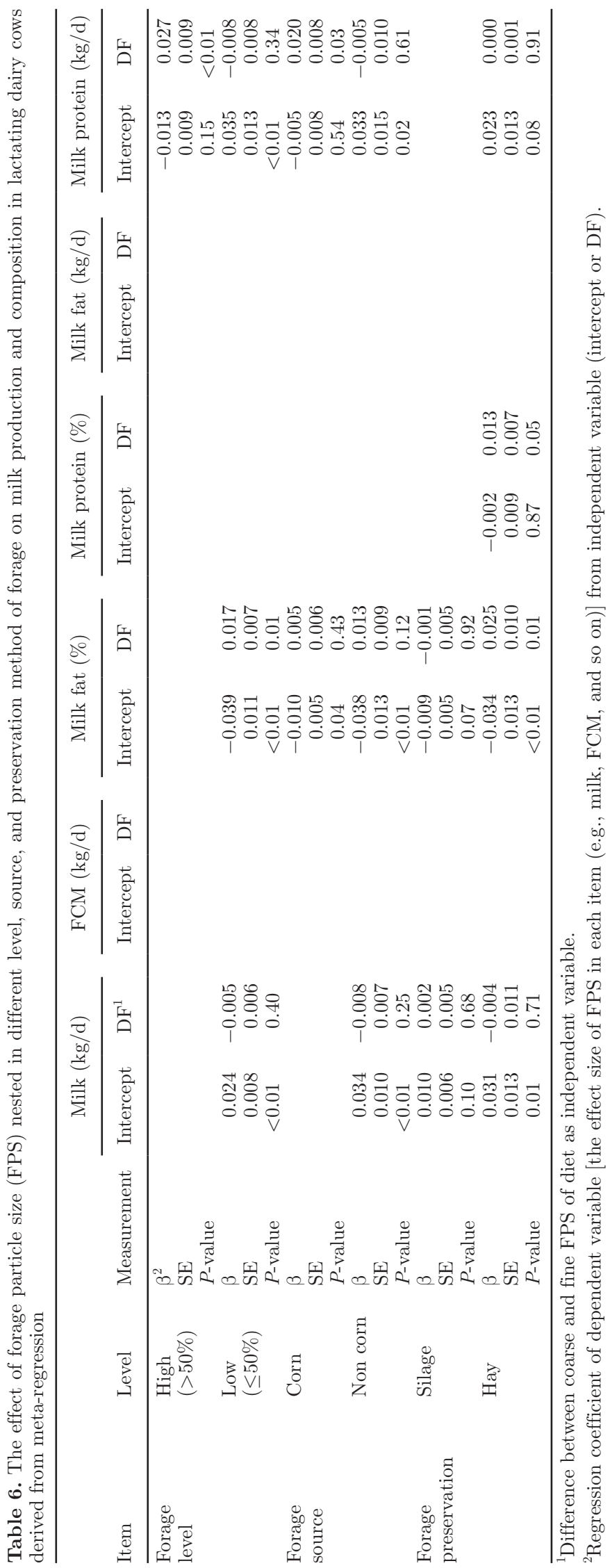

of FPS on nutrient intake. The decreasing and increasing effects on DMI at low and high levels of forage feeding, respectively, was an important outcome of our study and indicates a different role of FPS at different levels of forage feeding. Indeed, because the effect of gut filling on feed intake is stronger when high levels of forages are fed (Allen, 2000; Tafaj et al., 2001), it is understandable that DMI was increased with decreasing FPS at high levels of forage only. In contrast, in low-forage diets, the FPS and mechanical filling effects did not affect DMI (Allen, 2000). Due to depression of rumen $\mathrm{pH}$, hypotony in the rumen, and greater osmolarity (Owens et al., 1998), the feed intake can be depressed by decreasing FPS. In a modeling study, Zebeli et al. (2008) predicted a slight decline in DMI with low levels of physically effective fiber (peNDF), but DMI increased with average peNDF contents in the diet and decreased when diets were excessive in peNDF. From the perspective of the outcome of DMI, our data suggest that decreasing FPS is a useful tool to enhance DMI in cows in those regions of the world that feed high levels of forage, such as Europe, but not in North America and Iran.

The decreasing effect of FPS on DMI in noncorn forage-based diets compared with corn-based diets as well as in hay-based diets compared with diets based on silage might be in part due to decreasing feed palatability. Indeed, according to Tyle (1993) decreasing FPS of legumes, particularly in the form of hay, can impair the palatable leaves and the texture of forage, which happens more in hays and grasses and less in corn. Plant leaves and the texture of forage are important for palatability and voluntary intake of forages (Van Soest, 1994).

The reasons for improvement in DM digestibility with decreasing FPS in noncorn forage-based diets have not been discussed before. As well, starch digestibility improved with decreasing FPS in noncorn- and haybased diets when compared with corn- and silage-based diets, which cannot be fully explained with the existing information. The possible explanation for this improvement of digestibility in response to decreasing FPS might be an improved uniformity of diet when legume hay was fed (Zebeli et al., 2012). A better uniformity of the diet results in greater intake and better distribution of fiber, which is needed for formation of rumen mat and promotion of degradation in total digestive tract, as well as rumen heath and functioning (Zebeli et al., 2012), which are of key importance for nutrients to be digested appropriately in each segment of the digestive tract. In agreement with our findings, Kowsar et al. (2008) reported an increased in DM digestibility when fine particle of alfalfa hay was added to corn silagebased diet. 
The improvement in milk production with decreasing FPS in our study is interesting because previous research studies (Kononoff and Heinrichs, 2003a; Teimouri Yansari et al., 2004; Alamouti et al., 2009) and review articles (Zebeli et al., 2012), as well as meta-analyses (Zebeli et al., 2006; Tafaj et al., 2007), uniformly indicated no significant effect of FPS on milk production, although DMI was mostly improved in all these studies. In the current meta-analysis, we used a large number of experimental findings and a more precise statistical approach, which was able to detect even marginal effects of FPS. However, it should be stated that an increase of milk production of almost 0.5 $\mathrm{kg} / \mathrm{d}$ does not fully explain the increase of more than $0.5 \mathrm{~kg}$ of $\mathrm{DMI} / \mathrm{d}$. With this increase in DMI an increase of at least $1 \mathrm{~kg}$ of milk/d might have been expected. This indicates that only half of the additional feed energy and nutrients were used for milk production, and the other half probably for body mass increase. This disagreement could be explained by the fact that all studies used in the meta-analysis were short-term experiments, as suggested earlier by Zebeli et al. (2012) as the main reason why FPS improves DMI but milk production performance does not. Al-Trad et al. (2009) demonstrated that a short-term increase in the intravenous glucose supply enlarges body reserves but not milk yield.

We also found a decrease of milk fat percentage with decreasing FPS, confirming findings of previous studies on this issue (Zebeli et al., 2006, 2008); however, this contrasts with results reported previously by Tafaj et al. (2007), who detected a relationship with FPS only when fiber content of the diet was also considered in the model. The positive effects of FPS on milk fat content can be explained with the enhancing effect of coarse FPS on chewing activity, which helps prevention of ruminal pH depression (Zebeli et al., 2008). Indeed, the lowered ruminal $\mathrm{pH}$ may alter the rumen biohydrogenation process, resulting in the production of trans-10,cis-12 CLA and perhaps other unique FA, which are described as potent inhibitors of de novo milk fat synthesis in the mammary gland (Bauman and Griinari, 2001).

The effect of FPS and forage level in the diet on milk fat percentage is an unexpected result of the present study. Our meta-analysis indicated an increase of milk fat with decreasing FPS, but only at low levels of forage inclusion. However, this surprising effect of greater milk fat with decreasing FPS at low forage inclusion levels can likely can be explained by the fact that the chewing index (chewing time per kilogram of forage intake) increases with decreasing FPS in a low-forage diet (Zebeli et al., 2006), balancing the lower overall chewing activity. Another explanation could also be an increase in diet uniformity with decreasing FPS that prevents both feed sorting and increases absolute amount of diurnal fiber intake, with positive effects on milk fat at low levels of forage feeding (Zebeli et al., 2012).

The improvement of milk protein yield with decreasing FPS at high levels of forage inclusion could be explained by a better energy supply to cows due to an increase of DMI as well as an increased digestibility of starch (Nasrollahi and Khorvash, 2014). Similarly, the enhancement of milk protein production in corn forage-based diets with decreasing FPS might be due to an improvement in starch digestibility in the rumen and postruminally, with the possibility of increasing microbial protein synthesis, the availability of energy, and, hence, milk protein increment.

Interestingly, decreasing FPS improved milk protein and fat percentage in diets based on hay. The effect on milk protein could be explained by the increase of DMI and, hence, better energy availability in response to short FPS. Greater milk fat content due to short FPS in hay-based diets could be explained by less feed sorting, as hay is more prone to be sorted due to its density, which can be prevented by decreasing FPS (Nasrollahi et al. 2014). As a result, preventing feed sorting would prevent sorting against coarse particles of forage and improve rumen $\mathrm{pH}$ and fermentation, thus enhancing the milk fat. Another positive aspect of preventing feed sorting is the resulting uniform feeding with a synchronized delivery of fermentable energy and protein, which improves microbial protein synthesis and milk protein concentration (NRC, 2001). Also, hay in almost all studies was alfalfa hay, which, according to the NRC (2001), is a good source of $\mathrm{N}$ for microbial protein synthesis. Therefore, the improvement of milk protein with decreasing FPS in diets containing hay could be attributed to a better rumen microbial synthesis of protein.

\section{CONCLUSIONS}

This meta-analysis revealed improvements in DM and NDF intake with decreasing FPS, but a depression of NDF digestibility. However, the improvement in DMI, in particular, occurred with decreasing FPS for diets containing a high level of forage $(>50 \%)$. Also, the improvement in DMI due to lowering FPS was evident for diets containing silage but not hay. The study showed that digestibility of DM increased with decreasing FPS when the forage source was not corn silage. Most importantly, the study indicated improvement of milk yield and milk protein production with decreasing FPS. Milk fat percentage decreased in response to decreasing FPS in the diet. Furthermore, decreasing FPS in diet with a high level of forage inclusion increased 
milk protein production. In conclusion, FPS has the potential to affect DMI and performance of dairy cows but its effects are modulated by forage level, source, and preservation method.

\section{REFERENCES}

Al-Trad, B., K. Reisberg, T. Wittek, G. B. Penner, A. Alkaassem, G. Gäbel, M. Fürll, and J. R. Aschenbach. 2009. Increasing intravenous infusions of glucose improve body condition but not lactation performance in midlactation dairy cows. J. Dairy Sci. 92:5645-5658.

Alamouti, A. A., M. Alikhani, G. R. Ghorbani, and Q. Zebeli. 2009. Effects of inclusion of neutral detergent soluble fibre sources in diets varying in forage particle size on feed intake, digestive processes, and performance of mid-lactation Holstein cows. Anim. Feed Sci. Technol. 154:9-23.

Allen, M. S. 2000. Effect of diet on short-term regulation of feed intake by lactating dairy cattle. J. Dairy Sci. 83:1598-1624.

Bal, M. A., R. D. Shaver, A. G. Jirovec, K. J. Shinners, and J. G. Coors. 2000. Crop processing and chop length of corn silage: Effects on intake, digestion, and milk production by dairy cows. J. Dairy Sci. 83:1264-1273.

Bauman, D. E., and J. M. Griinari. 2001. Regulation and nutritional manipulation of milk fat: Low-fat milk syndrome. Livest. Prod. Sci. 70:15-29.

Beauchemin, K. A., W. Z. Yang, and L. M. Rode. 2003. Effects of particle size of alfalfa based-dairy cow diets on chewing activity, ruminal fermentation, and milk production. J. Dairy Sci. 86:630-643.

Begg, C. B., and M. Manumdar. 1994. Operating characteristics of arank correlation test for publication bias. Biometrics 50:10881101.

Behgar, M., R. Valizadeh, M. Mirzaee, A. A. Naserian, and S. Ghasemi. 2011. The impact of alfalfa hay particle size on the utilization of soy hull by early lactating dairy cows. Livest. Sci. 142:147-154.

Bhandari, S. K., S. Li, K. H. Ominski, K. M. Wittenberg, and J. C. Plaizier. 2008. Effects of the chop lengths of alfalfa silage and oat silage on feed intake, milk production, feeding behavior, and rumen fermentation of dairy cows. J. Dairy Sci. 91:1942-1958.

Bhandari, S. K., K. H. Ominski, K. M. Wittenberg, and J. C. Plaizier. 2007. Effects of chop length of alfalfa and corn silage on milk production and rumen fermentation of dairy cows. J. Dairy Sci. 90:2355-2366.

Calberry, J. M., J. C. Plaizier, M. S. Einarson, and B. W. McBridge. 2003. Effects of replacing chopped alfalfa hay with alfalfa silage in a total mixed ration on production and rumen conditions of lactating dairy cows. J. Dairy Sci. 86:3611-3619.

Clark, P. W., and L. E. Armentano. 1999. Influence of particle size on the effectiveness of the fiber in corn silage. J. Dairy Sci. 82:581588 .

Clark, P. W., and L. E. Armentano. 2002. Influence of particle size on the effectiveness of the fiber in alfalfa silage. J. Dairy Sci. 85:30003007.

Couderc, J. J., D. H. Rearte, G. F. Schroeder, J. I. Ronchi, and F. J. Santini. 2006. Silage chop length and hay supplementation on milk yield, chewing activity, and ruminal digestion by dairy cows. J. Dairy Sci. 89:3599-3608.

DeVries, T. J., F. Dohme, and K. A. Beauchemin. 2008. Repeated ruminal acidosis challenges in lactating dairy cows at high and low risk for developing acidosis: Feed sorting. J. Dairy Sci. 91:3958 3967.

Duffield, T. F., A. R. Rabiee, and I. J. Lean. 2008. A meta-analysis of the impact of monensin in lactating dairy cattle. Part 1 . Metabolic effects. J. Dairy Sci. 91:1334-1346.

Egger, M., G. Davey Smith, M. Schneider, and C. Minder. 1997. Bias in meta-analysis detected by a simple, graphical test. BMJ 315:629-634
Einarson, M. S., J. C. Plaizier, and K. M. Wittenberg. 2004. Effects of barley silage chop length on productivity and rumen conditions of lactating dairy cows fed total mixed ration. J. Dairy Sci. $87: 2987-2996$.

Fernandez, I., C. Martin, M. Champion, and B. Michalet-Doreau. 2004. Effect of corn hybrid and chop length of whole-plant corn silage on digestion and intake by dairy cows. J. Dairy Sci. 87:1298-1309.

Fleiss, J. L. 1993. The statistical basis of meta-analysis. Stat. Methods Med. Res. 2:121-145.

Higgins, J. P. T., S. G. Thompson, J. J. Deeks, and D. G. Altman. 2003. Measuring inconsistency in meta-analyses. BMJ 327:557560.

Jenkins, T. C., J. A. Bertrand, and W. C. Bridges Jr.. 1998. Interactions of tallow and hay particle size on yield and composition of milk from lactating Holstein cows. J. Dairy Sci. 81:1396-1402.

Johnson, L. M., J. H. Harrison, D. Davidson, W. C. Mahanna, and K. Shinners. 2003. Corn silage management: Effects of hybrid, chop length, and mechanical processing on digestion and energy content. J. Dairy Sci. 86:208-231.

Kahyani, A., G. R. Ghorbani, M. Khorvash, S. M. Nasrollahi, and K. A. Beauchemin. 2013. Effects of alfalfa hay particle size in highconcentrate diets supplemented with unsaturated fat: Chewing behavior, total-tract digestibility, and milk production of dairy cows. J. Dairy Sci. 96:7110-7119.

Kammes, K. L., and M. S. Allen. 2012. Nutrient demand interacts with grass particle length to affect digestion responses and chewing activity in dairy cows. J. Dairy Sci. 95:807-823.

Kammes, K. L., Y. Ying, and M. S. Allen. 2012. Nutrient demand interacts with legume particle length to affect digestion responses and rumen pool sizes in dairy cows. J. Dairy Sci. 95:2616-2631.

Kononoff, P. J., and A. J. Heinrichs. 2003a. The effect of corn silage particle size and cottonseed hulls on cows in early lactation. J. Dairy Sci. 86:2438-2451.

Kononoff, P. J., and A. J. Heinrichs. 2003b. The effect of reducing alfalfa haylage particle size on cows in early lactation. J. Dairy Sci. 86:1445-1457.

Kononoff, P. J., A. J. Heinrichs, and H. A. Lehman. 2003. The effect of corn silage particle size on eating behavior, chewing activities, and rumen fermentation in lactating dairy cows. J. Dairy Sci. 86:3343-3353.

Kowsar, R., G. R. Ghorbani, M. Alikhani, M. Khorvash, and A. Nikkhah. 2008. Corn silage partially replacing short alfalfa hay to optimize forage use in total mixed rations for lactating cows. J. Dairy Sci. 91:4755-4764.

Krause, K. M., and D. K. Combs. 2003. Effects of forage particle size, forage source, and grain fermentability on performance and ruminal pH in midlactation cows. J. Dairy Sci. 86:1382-1397.

Krause, K. M., D. K. Combs, and K. A. Beauchemin. 2002. Effects of forage particle size and grain fermentability in midlactation dairy cows. I. Milk production and diet digestibility. J. Dairy Sci. 85:1936-1946.

Le Liboux, S., and J. L. Peyraud. 1998. Effect of forage particle size and intake level on fermentation patterns and sites and extent of digestion in dairy cows fed mixed diets. Anim. Feed Sci. Technol. $73: 131-150$

Le Liboux, S., and J. L. Peyraud. 1999. Effect of forage particle size and feeding frequency on fermentation patterns and sites and extent of digestion in dairy cows fed mixed diets. Anim. Feed Sci. Technol. 76:297-319.

Leonardi, C., K. J. Shinners, and L. E. Armentano. 2005. Effect of different dietary geometric mean length particle length and particle size distribution of oat silage on feeding behavior and productive performance of dairy cattle. J. Dairy Sci. 88:698-710.

Maulfair, D. D., M. Fustini, and A. J. Heinrichs. 2011. Effect of varying total mixed ration particle size on rumen digesta and fecal particle size and digestibility in lactating dairy cows. J. Dairy Sci. 94:3527-3536.

Maulfair, D. D., and A. J. Heinrichs. 2013. Effects of varying forage particle size and fermentable carbohydrates on feed sorting, ruminal fermentation, and milk and component yields of dairy cows. J. Dairy Sci. 96:3085-3097. 
Maulfair, D. D., G. I. Zanton, M. Fustini, and A. J. Heinrichs. 2010. Effect of feed sorting on chewing behavior, production, and rumen fermentation in lactating dairy cows. J. Dairy Sci. 93:4791-4803.

Mertens, D. R. 1993. Kinetics of cell-wall digestion and passage in ruminants. Pages 535-571 in Forage Cell Wall Structure and Digestibility. H. G. Jung, D. R. Buxton, R. D. Hatfield, and J. Ralph, ed. American Society of Agronomy, Crop Science Society of America, Soil Science Society of America, Madison, WI.

Mertens, D. R. 1997. Creating a system for meeting the fiber requirements of dairy cows. J. Dairy Sci. 80:1463-1481.

Nasrollahi, S. M., G. R. Ghorbani, M. Khorvash, and W. Z. Yang. 2014. Effects of grain source and marginal change in lucerne hay particle size on feed sorting, eating behaviour, chewing activity, and milk production in mid-lactation Holstein dairy cows. J. Anim. Physiol. Anim. Nutr. (Berl.) 98:1110-1116.

Nasrollahi, S. M., and M. Khorvash. 2014. Carbohydrates in Dairy Cow Nutrition. 1st ed. Khotan Publication, Tehran, Iran.

Nasrollahi, S. M., M. Khorvash, G. R. Ghorbani, A. Teimouri-Yansari, A. Zali, and Q. Zebeli. 2012. Grain fermentability and marginal changes in forage particle size modulated digestive processes, and nutrient intake in dairy cows. Animal 6:1237-1245.

NRC. 2001. Nutrient Requirements of Dairy Cattle. 7 th rev. ed. Natl. Acad. Sci., Washington, DC.

Onetti, S. G., S. M. Reynal, and R. R. Grummer. 2004. Effect of alfalfa forage preservation method and particle length on performance of dairy cows fed corn silage-based diets and tallow. J. Dairy Sci. 87:652-664.

Onetti, S. G., R. D. Shaver, S. J. Bertics, and R. R. Grummer. 2003. Influence of corn silage particle length on the performance of lactating dairy cows fed supplemental tallow. J. Dairy Sci. 86:29492957.

Owens, F. N., D. S. Secrist, W. J. Hill, and D. R. Gill. 1998. Acidosis in cattle: A review. J. Anim. Sci. 76:275-286.

Puggaard, L., P. Lund, and J. Sehested. 2013. Effect of feed forage particle size and dietary urea on excretion of phosphorus in lactating dairy cows. Livest. Sci. 158:50-56.

Rabiee, A. R., K. Breinhild, W. Scott, H. M. Golder, E. Block, and I. J. Lean. 2012. Effect of fat additions to diets of dairy cattle on milk production and components: A meta-analysis and metaregression. J. Dairy Sci. 95:3225-3247.

Rabiee, A. R., and I. J. Lean. 2013. The effect of internal teat sealant products (Teatseal and Orbeseal) on intramammary infection, clinical mastitis, and somatic cell counts in lactating dairy cows: A meta-analysis. J. Dairy Sci. 96:6915-6931.

Rosenthal, R. 1979. The "file drawer problem" and tolerance for null results. Psychol. Bull. 86:638-641.

Russell, J. B., and D. B. Wilson. 1996. Why are ruminal cellulolytic bacteria unable to digest cellulose at low pH? J. Dairy Sci. 79:1503-1509.

Schwab, E. C., R. D. Shaver, K. J. Shinners, J. G. Lauer, and J. G. Coors. 2002. Processing and chop length in brown midrib corn silage on intake, digestion, and milk production by dairy cows. J. Dairy Sci. 85:613-623.

Soita, H. W., D. A. Christensen, and J. J. McKinnon. 2000. Influence of particle size on the effectiveness of the fiber in barley silage. J. Dairy Sci. 83:2295-2300.

Soita, H. W., M. Fehr, D. A. Christensen, and T. Mutsvangwa. 2005. Effects of corn silage particle length and forage: Concentrate ratio on milk fatty acid composition in dairy cows fed supplemental flaxseed. J. Dairy Sci. 88:2813-2819.

Storm, A. C., and N. B. Kristensen. 2010. Effects of particle size and dry matter content of a total mixed ration on intraruminal equilibration and net portal flux of volatile fatty acids in lactating dairy cows. J. Dairy Sci. 93:4223-4238.

Tafaj, M., H. Steingass, and W. Drochner. 2001. Influence of hay particle size at different concentrate and feeding levels on digestive processes and feed intake in ruminants. 2. Passage, digestibility and feed intake. Arch. Tierernahr. 54:243-259.

Tafaj, M., Q. Zebeli, Ch. Baes, H. Steingass, and W. Drochner. 2007. A meta-analysis examining effects of particle size of total mixed rations on intake, rumen digestion and milk production in highyielding dairy cows in early lactation. Anim. Feed Sci. Technol. 138:137-161.

Teimouri Yansari, A., and R. Primohammadi. 2009. Effect of particle size of alfalfa hay and reconstitution with water on intake, digestion and milk production in Holstein dairy cows. Animal 3:218-227.

Teimouri Yansari, A., R. Valizadeh, A. Naserian, D. A. Christensen, P. Yu, and F. Eftekhari Shahroodi. 2004. Effects of alfalfa particle size and specific gravity on chewing activity, digestibility, and performance of Holstein dairy cows. J. Dairy Sci. 87:3912-3924.

Tyle, P. 1993. Effect of size, shape and hardness of particles in suspension on oral texture and palatability. Acta Psychol. (Amst.) 84:111-118.

Van Soest, P. J. 1994. Nutritional Ecology of the Ruminant, 2nd ed. Cornell University Press, Ithaca, NY.

Viechtbauer, W. 2010. Conducting meta-analyses in R with the metafor package. J. Stat. Softw. 36:1-48.

Walsh, S. W., E. J. Williams, and A. C. O. Evans. 2011. A review of the causes of poor fertility in high milk producing dairy cows. Anim. Reprod. Sci. 123:127-138.

Yang, W. Z., and K. A. Beauchemin. 2005. Effects of physically effective fiber on digestion and milk production by dairy cows fed diets based on corn silage. J. Dairy Sci. 88:1090-1098.

Yang, W. Z., and K. A. Beauchemin. 2006a. Effects of physically effective fiber on chewing activity and ruminal $\mathrm{pH}$ of dairy cows fed diets based on barley silage. J. Dairy Sci. 89:217-228.

Yang, W. Z., and K. A. Beauchemin. 2006b. Physically effective fiber: Method of determination and effects on chewing, ruminal acidosis, and digestion by dairy cows. J. Dairy Sci. 89:2618-2633.

Yang, W. Z., and K. A. Beauchemin. 2007. Altering physically effective fiber intake through forage proportion and particle length: Digestion and milk production. J. Dairy Sci. 90:3410-3421.

Yang, W. Z., and K. A. Beauchemin. 2009. Increasing physically effective fiber content of dairy cow diets through forage proportion versus forage chop length: Chewing and ruminal pH. J. Dairy Sci. 92:1603-1615.

Yang, W. Z., K. A. Beauchemin, and L. M. Rode. 2001. Effects of grain processing, forage to concentrate ratio, and forage particle size on rumen $\mathrm{pH}$ and digestion in dairy cows. J. Dairy Sci. 84:2203-2216.

Zebeli, Q., B. N. Ametaj, B. Junck, and W. Drochner. 2009. Maize silage particle length modulates feeding patterns and milk composition in loose-housed lactating Holstein cows. Livest. Sci. 124:33-40.

Zebeli, Q., J. R. Aschenbach, M. Tafaj, J. Boguhn, B. N. Ametaj, and W. Drochner. 2012. Invited review: Role of physically effective fiber and estimation of dietary fiber adequacy in high-producing dairy cattle. J. Dairy Sci. 95:1041-1056.

Zebeli, Q., J. Dijkstra, M. Tafaj, H. Steingass, B. N. Ametaj, and W. Drochner. 2008. Modeling dietary fiber adequacy in dairy cows based on responses of ruminal $\mathrm{pH}$ and milk fat production to diet composition. J. Dairy Sci. 91:2046-2066.

Zebeli, Q., M. Tafaj, H. Steingass, B. Metzler, and W. Drochner. 2006. Effects of physically effective fiber on digestive processes and milk fat content in early lactating dairy cows fed total mixed rations. J. Dairy Sci. 89:651-668.

Zebeli, Q., M. Tafaj, I. Weber, J. Dijkstra, H. Steingass, and W. Drochner. 2007. Effects of dietary hay particle size and concentrate level on chewing activity, ruminal mat characteristics and passage in dairy cows fed restricted. J. Dairy Sci. 90:1929-1942.

Zom, R. L. G., G. André, and A. M. Van Vuuren. 2012. Development of a model for the prediction of feed intake by dairy cows: 1 . Prediction of feed intake. Livest. Sci. 143:43-57. 